IRA-International Journal of Management \& Social Sciences

ISSN 2455-2267; Vol.07, Issue 02 (2017)

Pg. no. 213-222

Institute of Research Advances

http://research-advances.org/index.php/RAJMSS

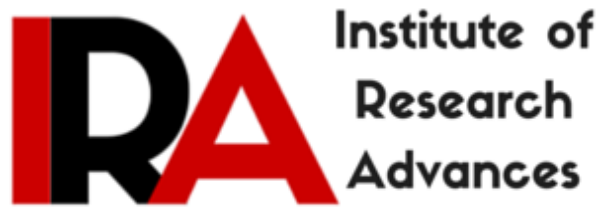

\title{
The Question of British Southern Cameroons' Autonomy in the Evolution of Nigeria Federation, 1945-1961
}

\section{Mathias Azang Adig}

Head of Division of Admissions and Records in the Higher Institute of Transport and Logistics \& Associate Lecturer, Department of History of The University of Bamenda, Cameroon.

Type of Review: Peer Reviewed.

DOI: http://dx.doi.org/10.21013/jmss.v7.n2.p11

\section{How to cite this paper:}

Adig, M. (2017). The Question of British Southern Cameroons' Autonomy in the Evolution of Nigeria Federation, 1945-1961. IRA-International Journal of Management \& Social Sciences (ISSN 2455-2267), 7(2), 213-222. doi:http://dx.doi.org/10.21013/jmss.v7.n2.p11

(C) Institute of Research Advances

\section{(cc) EY-NC}

This work is licensed under a Creative Commons Attribution-Non Commercial 4.0 International License subject to proper citation to the publication source of the work.

Disclaimer: The scholarly papers as reviewed and published by the Institute of Research Advances (IRA) are the views and opinions of their respective authors and are not the views or opinions of the IRA. The IRA disclaims of any harm or loss caused due to the published content to any party. 


\begin{abstract}
The connection of Southern Cameroons to the Nigerian Federation by Britain after the First World War, worked to the disadvantage of Southern Cameroons' sovereignty and political ambitions. With her international status as a Trust Territory, Southern Cameroons was marginalized by the colonial administration which failed to recognize her as a separate territory within the Nigerian Federation. Under such dispensation, Southern Cameroonians felt that for such a Nigerian connection to be of any benefit to the territory, it should be granted an autonomous regional status in line with the existing regions in Nigeria. This strain of relations caused Cameroonians to animate Nigeria political scene with series of events which became very instrumental in influencing the direction and nature of the evolution of the Nigerian federation. This feud for regional autonomy which dominated Nigerian politics was undertaken by pressures groups, political parties, and at individual levels through vocal voices, petitions, conferences and walkouts which expressed their grievances. The paper argues that the granting of quasi and full regional status in 1954 and 1959 respectively to Southern Cameroons was a consequence of their demonstrations. On this score Nigeria rose from three to four regions under colonial rule. From this paradigm we conclude that the history of the evolution of Nigerian federation can never be complete without the Southern Cameroons factor. Archival data and analyses of existing literature have provided evidence for this conclusion.
\end{abstract}

Keywords: Colonial administration, Southern Cameroons, Nigeria federation, Autonomy

\title{
Introduction
}

The First World War which resulted in the defeat of Germany was the spring board for the further balkanization and reattribution of some African territories that had been colonized by Germany. The failure of the Anglo-French 'Condominium' over German Kamerun in 1916 resulted in the partition of the territory between the two powers at a ratio of 1:4 [Elango L. 1986]. For administrative conveniences, Britain decided to administer her own portion of the territory as an integral part of her adjacent territory of Nigeria. Owing to the disjointed nature of British Cameroon, the northern portion was incorporated into the Northern region of Nigeria while the southern portion was incorporated and administered as an integral part of Southern Nigeria. As Ngoh [1960:3] explains, the southern portion of British Cameroon became known as the Cameroon Province. ${ }^{1}$ By such arrangements, the Cameroon Province left the German system with the Kamerun idea to become a fragment of the Nigerian federal system under the British; a system that was introduced in the colony of Nigeria because of the fragmented manner in which Britain acquired the territory. According to O'Connell J.[1967:133], by 1900, Britain had Nigeria in three fragments: the Colony of Lagos, the protectorate of the Southern Nigeria, and the protectorate of the Northern Nigeria. The separate administrations of the three entities with different ethnic compositions under a common Crown laid the foundation of the Nigerian federalism. The acquisition and administration of the British Cameroons as an appendage of Nigeria epitomize another extension of the inter-ethnic fragmented nature which Britain acquired and administered the colony of Nigeria.

In this arrangement, the Southern Cameroons was further attached as a province of the Eastern Nigeria in 1922. Such a subordinate position was very disturbing since Southern Cameroons could not express herself as an autonomous region like the other regions of Nigeria. As such the administrative arrangement received less admiration from Southern Cameroonians. Consequently, the greatest issue advanced and debated by Southern Cameroonians as an appendage of Nigeria under Britain according to Amaazee [2000:98-100], was the question of autonomy for the territory. Although the request was

\footnotetext{
1

For the purpose of this study I have decided to call the Cameroon Province which is the subject of our study from 1922 to 1961 , Southern Cameroons, although it was only in 1957 that the appellation was constitutionally recognized. By 1922, Southern Cameroons was attached as a province to Southern Nigeria. When the Richards' Constitution was promulgated in 1946 and Nigeria divided into three regions, the territory Southern Cameroons became a province of Eastern region. However, from 1949 when the Bamenda Division was raised to a full province and became known as the Bamenda Province, the coastal region of British Southern Cameroons, which is today the South West Region, became known as the Cameroon Province.
} 
turned down by the British authorities, it finally came to fruition in 1954 when she was granted a quasi-region and a full region in 1957. Therein, Southern Cameroons formed the fourth region by every practical definition and fair appraisal of the Nigerian federal system under colonial rule.

This write-up articulates on how Southern Cameroonians animated the political scene within Nigeria in their quest for regional status and argues that the road to a regional status for Southern Cameroons was thorny and complicated. It opines that had Southern Cameroonians remained silent, the history of the Nigerian federal system under colonial rule would have ended with three regions. The argument is substantiated with facts which illustrate how the requests were done through speeches, petitions, conferences and walk-outs, in Cameroon, Nigeria, Britain and the UN to express their distrust and desire to become a major stakeholder in Nigerian politics as an autonomous entity.

\section{Theoretical Conception}

Generally, a subordinated status in any given circumstance is discomforting and "when a group perceives itself down the hierarchy in the federal relationship, its main purpose is to obtain more power, that is, to free itself from the control of the dominant group,' [Aka E.,2002:183fn7]. Such a situation was very glaring in Nigeria where the dominant ethnic groups were more interested in maintaining the status quo while the minority groups feel unsecured and dissatisfied because they would never have the position to wield political power in the government for their interest. The struggle for autonomy by the minority groups was because in a federal arrangement, power within a country is shared between the central authority, and the regional governments. Each unit in such a system exists as a central authority with a separate government independent from the others. It operates directly on the persons and property within its territorial area, with a will of its own and its own apparatus for the conduct of affairs. Each government exists, not as an appendage of another (e.g. the federal or central government) but as an autonomous entity. Thus, on the one hand the Central Government and the on the other the Regional Governments as autonomous entities in their respective spheres. It is important to note here that only groups of the same should come within a zone and Southern Cameroons being of a dissimilar national origin and not of the same group with any Nigerian group could only be comfortable in such a system as a separate region of its own. Faced with the conflicting demands for autonomy by the various political groupings, Britain was compelled to introduce a federal system of government in the various constitutional drafts in order to establish a measure of compromise to accommodate various demands. That is why the history of Federalism in Nigeria can be traced to the division of the country into three (3) provinces in 1939, regions in the Arthur Richard's Constitution in 1946, Richard's constitution, Macpherson's constitution in 1953 and the Lyttleton constitution in 1954 which concluded with a Federal system of government for the country.

Southern Cameroons in their minority position and as a province of a region was therefore not left behind in the request to free herself and express her territorial ambitions. Her interest in the first place was to separate from the Eastern region since she was technically not a colony and its inhabitants hardly considered themselves as part of Nigeria. By 1946 when Southern Cameroons changed international status, this affected her standing as a colonial territory and the need for a regional status became more pressing. By transforming Southern Cameroons from a Mandate to a Trust Territory, Britain was given other international responsibilities which included the preparation of the territory for eventual self-rule. But within the Nigerian frame-work Southern Cameroonians felt like outsiders because of the German colonial experience, the international status and the discriminatory way in which they were treated and marginalized by Nigerians. The voices of Southern Cameroonians could hardly be heard in the Eastern Regional House of Assembly where they occupied 13 seats out of a total of eighty under the Macpherson Constitution. As a minority bloc, they were not in a position to effectively influence the house to take their interest into consideration. In the face of Southern Cameroons' frustration under Nigeria the people accentuated the various conferences in demand for regional autonomy for the territory. It is under such concepts that the quest for an autonomous regional status for the minority and disadvantaged Southern Cameroonians under alien rule gained ground and is worth this study. 


\section{Southern Cameroons Connection to Nigeria}

The impetus to the Cameroon and Nigeria connection was directed more by international events of the period than from constitutional developments in Nigeria. The post World War 1 international negotiations from 1918 to 1923 were instrumental in connecting Southern Cameroons with Nigeria. The war which resulted into the defeat of the Germans in Cameroon by the Allied Powers in February 1916 led to the partition of the territory of German Kamerun between Britain and France. On the $20^{\text {th }}$ July 1922, France and Britain were granted League of Nations mandates over their respective zones of occupation. The existence of geographical barriers and the absence of an adequate transportation and communication network between the two disjointed strips of the British portion of the territory 'made its effective administration' as a single unit, separate from Nigeria extremely difficult and expensive. For administrative and financial conveniences, Britain divided her sphere of German Kamerun into two parts- a northern section called Northern Cameroons and a southern section known as the Southern Cameroons [Ngoh, 1990:3].

When the Covenant of the League of Nations was signed on July 20, 1922 and Clifford Constitution drawn,[ibid,2002: 10-11], Southern Cameroons which measured 16,581 square miles was administered as an integral province of the British protectorate of Southern Nigeria. Northern Cameroons on the other hand was incorporated and administered as part of the Northern protectorate of Nigeria. In 1939 when Bernard Bourdillon attempted to revise the 1922 constitution, Southern Nigeria was divided into the Western and Eastern Regions; Southern Cameroons became connected to Nigeria as a province of the Eastern Region of Nigeria. The Southern Cameroon province was placed under a Senior Resident in Buea who was responsible to the Lieutenant Governor of the Eastern Region based in Enugu, the regional capital [Eyongetah and Brain, 1974:95].

\section{Cameroons Frustrations in the Nigerian Connection}

The decision to administer Southern Cameroons as an integral part of the Eastern region of Nigeria was single handedly taken by Britain as the colonial authority. It was decided without consulting either the Nigerians or the Southern Cameroons. It is but obvious that if the question was put to the two parties right from the initial years on either to bring them together or not, it is natural that not all Nigerians and Southern Cameroonians would have approve of the union. But the British policy towards Southern Cameroons was to administer the territory as a province of a region in Nigeria and not as an autonomous region of the Nigerian federation. The absence of any recognized status for Southern Cameroons was the critical point of the frustration of the territory's political, economic and social ambitions.

By administering Southern Cameroons as an attachment of Nigeria, Britain had placed the territory in a relegated position, in which she was deprived of her political, economic and social aspirations. The Cameroonians were like victims of war, torn apart from their kith and kin and obliged by circumstances to live among new Africans and to lean new ways. [Amaazee, 2000:7]. This era came after 30 years of colonial rule under which they had imbibed German education, culture and a rigid discipline. DeLancey et al [2010:5] posits that the result of such an arrangement was that Southern Cameroons connections with Nigeria were sometimes referred to, derogatorily as a "colony within a colony". According to Amaazee,[2000: 11-18], this was more so because Southern Cameroons was attached to the Eastern region that was dominated by the Igbo ethnic group which treated Cameroonians as under dogs.

The extreme poor means of communication which limited the economic and social development of Southern Cameroons as a result of British neglect of the territory infuriated many Southern Cameroonians. Apart from making the administration of the territory difficult, it also isolated a majority of the people from the centres of modernization and from the main channels of trade.

In financial matters, Southern Cameroonians felt in a disadvantageous position in the method and amount of revenue allocated to the territory. Before 1955, Southern Cameroons was not attributed a budget of its own. According to the 1951 Commission report such a budget depended on the so-called 
'special obligation of the Nigeria government.' The generous grant from Nigeria was not based on any rational criteria, but on the whims and caprices of the administrative officers. Financial dealings with Southern Cameroons became scandalous from 1955, when the region had been separated from the Eastern Region of Nigeria. Even when it was discovered that the region's share of the financial allocations were not rightly allocated, nothing was done to redress it.

Cameroonian frustration in their association with Nigeria was magnified by the predominance of Nigerians, especially the Igbo ethnic group in Southern Cameroons which naturally created a strong dislike for the Igbos. The number of Igbos in the towns and villages of Southern Cameroons was alarming, that by the 1953 census, there were over 838000 Nigerians in Cameroon, out of which 258000 were Igbos [Aka E, 2002:165]. Nationalists' involvement in Southern Cameroons was therefore, 'more of anti-Igbo, anti-Nigerian than anti-British'.

Apart from the discriminations and corrupt practices, the Igbos were noted for the numerous atrocities which they were generally associated with in Southern Cameroons. These atrocities that were isolated were numerous and scandalous. The propaganda about Igbo atrocities be it real or rumours was so affective that passionate outbursts of speakers carried the feelings and made rational discussions difficult. It was in the wake of such circumstances that Igbos in Cameroon were often targets of Cameroonian frustration and were used as a major reason to demand for political separation from Nigeria [Amaazee, 2000:16-19]. It was against this backdrop that a reaction or reactions against specific grievances were to culminate, in time, into the genuine nationalist feelings in the form of a quest for a regional status first and later independence

\section{The Quest for Regional Autonomy and Identity}

An important twist in the history of British Cameroon was the administration of the territory as an integral part of Nigeria and not as a separate bloc with a distinct international status. It was not even administered as a separate region within Nigeria but as a province of a region. This was the origin of the Cameroon frustration in the Nigerian frame-work which provoked the quest for identity through the creation of a separate region which would have the right to its aspirations as a people. It sums that the connection of Southern Cameroons to the Federation of Nigeria by Britain, was a single handed decision which worked less to the advantage of Southern Cameroons' sovereignty and ambitions. But the British were determined to administer Southern Cameroons as a separate province of a region in Nigeria and not as an autonomous region in Nigerian. The absence of such recognized status for Southern Cameroons frustrated the territory's political, economic and social ambitions.

The request for a separate autonomous region for Southern Cameroons in line with the other regions of Nigeria became a topical issue during the numerous conferences held in, Nigeria, London, the UN headquarters and Southern Cameroons on matters concerning colonial administration. During the various forums, Southern Cameroonians had the opportunities to express their grievances against colonial administration in Nigeria. Southern Cameroonians expressed its dissatisfaction through pressure groups, political parties, delegations, and on individual basis by writing petitions, making public speeches and open debates in the various forums. It should be noted that Southern Cameroons was not out for complete autonomy at the time, but rather a separate region within the existing federal frame work in Nigeria.

The available sources reveal that the first reaction to the British policies in Southern Cameroons in request for a regional status was raised in 1939 by the Cameroon Welfare Union (CWU) formed by G.J. Mbene [Kale, 1967:21]. It wrote petitions to the British, requesting representation for the Southern Cameroons in the Nigerian Central Legislative Assembly in Lagos [ibid]. This request was a direct challenge to the British political reorganisation of Southern Cameroon. Only the three regions into which Nigeria was divided could be represented at Lagos in their own rights. Southern Cameroons was as part of the Eastern region and could not, therefore be represented at Lagos in its own right. British reaction to the request could be expected. 'In this the administrating authority and then Union were at daggers drawn' [ibid, 21-22]. The expectancy for Cameroon autonomy gave birth 
to a new movement called the Cameroon Youth League (CYL) on March 27, 1940 which replaced the CWU which had dwindled into oblivion [ibid:36].

The CYL which took the same structure like the NYM thus became the first organization formed, to stimulate interest in the establishment of a Southern Cameroons region, especially when it had gained the international status as a trust territory[NAB,(1948)1]. The aim of the CYL was to redress the economic, educational, political and social grievances of British Cameroonians. Politically it aimed at arousing the national consciousness of British Cameroonians as well as seeking a recognized status for the Southern Cameroons [Ngoh, 1987:184]. By seeking for a recognised status, the CYL was requesting the creation of a Southern Cameroons region within Nigerian.

It would however appear that the eventual demand by the CYL, for an autonomous region from the Eastern region was not initially thought of otherwise it would not have participated in the formation of, and allied itself with the NCNC. The idea only evolved, notwithstanding its alliance with the NCNC, as the years went by and as Johnson [1970:114] asserts, 'out of a conviction that the territory was being exploited by Nigeria'. Even if the Southern Cameroons separated from the Eastern region, the possibility of ultimately seceding from the federation of Nigeria might have been ruled out, by that time. In fact, a number of Southern Cameroons leaders stated that 'separation from the Eastern region (would not mean) complete secession from Nigeria, but represented popular wish' [Aka E., 2002:182].

In 1947, when the Richard's constitution came into force, Endeley founded a political discussion group called, the Cameroon Federal Union (CFU), against Igbo domination, arrogance and monopoly in trade. Its main request was for a separate regional status for the Southern Cameroons. This regional status was seen by Dr. Emmanuel Endeley and his group as the surest way to eradicate Igbo supremacy in politics and business or simply reduce Igbo influence in the Southern Cameroons [Chem, 1976:40]. The CFU therefore simply kept alive the objectives first suggested by the CYL. The CFU petition pointed out that for more than thirty years, the British trust territories of the Cameroons had suffered from much neglect because it was administered as an integral part of Nigeria [Aka E., 2002:186].

Although it was after the promulgation of the Richards constitution into law in 1947 that the request for a separate region became vigorously pursued, Southern Cameroonians strongly criticized the constitution for not having granted the territory a regional status. At the same time the strongly criticized constitution, 'constituted the cradle of regionalism for Nigerians, though it left the status quo ante little change for Southern Cameroonians'[Ngo, 1990:46]. To foster Southern Cameroons demand, P.M. Kale joined a seven man NCNC delegation to London to petition against the Richards Constitution to the secretary of State for colonies, Arthur Creech Jones. Kale's request for a regional status for Southern Cameroons was unequivocally rejected by Creech Jones that, it was difficult because 'the Cameroons was a Trust Territory... (which) was incorporated in the political and economic life of Nigeria'[Kale, 1967:34] In an organized procession by the NCNC delegation through the streets of London in 1947 which ended with a meeting at Trafalgar square, speaker after speaker, expressed their grievances and disappointment with response from the Secretary of State for Colonies. On taking the podium, Kale called for the independence of Nigeria with Southern Cameroons as a region within it [NAB, Vc/a (1951)2].

The Richards Constitution though rejected was the catalyst to the evolution of federalism cherished by most nationalist leaders in Nigeria, especially those of the minority ethnic groups. It is important to note that, the provision of the constitution that went in a federal direction drew little protest from the nationalist leaders. It had respected the principles of regional representation and introduced it on the basis of the existing administrative units in Nigeria. It was therefore as a result of political developments in Nigeria, such as the Richards Constitution that the demand for separation was promoted in Southern Cameroons. When the Richards Constitution, initiated the process of federalism, various political leaders began advocating that Nigeria be further split into more than three regions. Southern Cameroon leaders were inspired by this trend of events in Nigeria and by the 
General anti-colonial sentiments that emerged after the Second World War and gave birth to the irresistible idea of self determination.

The Cameroonian nationalists had the opportunity to express their grievances and present their request for a separate autonomous region to the world, when the first United Nations Visiting Mission came to Cameroon in 1949.The most popular grievance presented by the many groups and individuals, was the absence of a separate regional organization for the Cameroons within the existing Nigerian constitution. However, in no case was complete separation from Nigeria demanded in 1949. Even when requests were made for the unification with the Cameroons under French administration, there were coupled with a desire to remain within the frame-work of the Nigerian constitution. The separatists were invariably for a greater degree of autonomy, but on purely regional bases, and with the same association that existing regions of Nigeria itself enjoyed with the constitutional structure of the country as a whole.

The outstanding exposition of the complaints was contained in the memorandum of the Cameroons National Federation (CNF), which acted for the purpose of the mission's visit as a spokesman for a number of tribal and community associations and unions. ${ }^{2}$ All the resolutions of the inaugural meetings of the C.N.F. held on May $14^{\text {th }}$ and $15^{\text {th }} 1949$, [UN. Doc., 1949: T/Pet.4/16/T/Pet 5/7] were presented to the UN visiting mission as petitions. During this meeting, Nerius Namaso Mbile tabled a motion to the effect:

That the Southern Cameroons be constituted into a separate region under a High Commissioner, who shall be responsible straight to the Trusteeship Council of the UN, through the governor of Nigeria, that the Cameroons be provided with a regional house exercising not only legislatives but executive powers [ Aka E.2000:185].

N. N. Mbile, like the leaders of the CWU, CYL and CFU, was therefore interested in the preservation of the identity of Southern Cameroons and the autonomy of the Southern Cameroons within Nigeria.

In a separate statement, an official of the $\mathrm{CNF}$, speaking as a member of a delegation from the Mamfe division mounted the stage and presented a speech to persuade the mission to recommend that the 'integral part' provision of Trusteeship Agreement be deleted. To him, without the integral clause, Southern Cameroons would not have been administered as an attached part of the Eastern region of Nigeria, but would have easily been administered as a separate region within the British federal system in Nigeria.

Regional status for the Trust Territory of Cameroons, as envisaged by these petitioners, did not imply separation from Nigeria. But it involved creating a fourth administrative region in addition to those into which Nigeria was already divided. The principal changes were that the Cameroons, while remaining within the frame work of the Nigerian Constitution and continuing to be administered as part of Nigeria, would be granted a measure of legislative, budgetary and administrative decentralization similar to that enjoyed by the three existing regions.

When the UN Mission Visiting Mission to Cameroon turned to discuss the problem of British Cameroons with the British authorities in Nigeria, the response was unequivocal objection. The authorities complained that the granting Southern Cameroons alone a separate region would demand a substantial financial contribution from the Eastern regional funds. In all, the decision of the constitutional conferences and the opinions of the UN Visiting Mission could not be final and binding. The ultimate decision rested with the administering authority itself, which in the opinion of the UN mission, was fully alive to the need of safeguarding the interest of the Trust Territory [Cited

\footnotetext{
${ }^{2}$ The CNF was born out of a meeting of all the 22 tribal organizations, including the CDC Workers Union summoned by the CYL at Kumba on May 14, 1949, a few months before the arrival of the mission. Endeley became its president and Mbile his vice.
} 
in UN Mission, 1952:15]. In the end, the administering authority made the decision by way of the Macpherson Constitution of 1951.

Meanwhile, in preparation for a revision of the Richards Constitution, Sir John Macpherson who had replaced Arthur Richard as the British Governor for the Territory, requested proposal for the new constitution. Again, the demand for a separate region, by the Southern Cameroons delegates was out-voted right at the Eastern Regional Constitutional Conference and was not adopted in the draft from the region for the Ibadan Conference. The conference rejected the request and argued that, it was difficult to organize a region, given the position of the British Northern Cameroons Trust Territory [NAB, (1939)/2]. At the General Constitutional Conference at Ibadan in 1950 where Endeley forced his way to pressed hard for a separate region for his territory, his opinion was notwithstanding rejected [Cited in Government Printers, 1950:141]. Instead, the Macpherson Constitution of 1951gave Southern Cameroons 13 seats in the Eastern Nigeria House of assembly. This set-up frustrated Southern Cameroons aspirations for a region.

\section{The Point of No Return}

The event that gave the opportunity to Southern Cameroonians to take a decisive stance to bring a turn of tide on their demand for regional status was the crisis that erupted in the Eastern House of Assembly in 1953. The Eastern Regional Crisis of 1953 caused both the abolition of the Macpherson Constitution and marked a turning point in the shilly-shally attitude of the British and Nigerian towards the Cameroonian request.The Benevolent Neutrality Bloc of the Southern Cameroons delegation therefore decided to severe links with the Eastern Region. They called on all the peoples of the Cameroons to support the demand for a separate region for the territory. A message was circulated throughout the territory inviting delegates of all works of life, for a meeting at Mamfe from May 22nd to 24th, 1953. At the massively attended conference, it was agreed that a petition be sent to Lord Oliver Lyttleton, the Secretary of State for Colonies. The petition demanded the creation of a separate and autonomous legislature for the Trust Territory, [Amaazee, 2000:5673].

In order to break the dead-lock over the collapse of the Macpherson Constitution and the fervent stance taken by the Southern Cameroonians, the British Government convened the London Conference of July $30^{\text {th }}$ to August $22^{\text {nd }} 1953$. At the conference the, the Colonial Secretary responded partially to the Southern Cameroons request. As he puts it, if Dr. Endeley's separatist party - the Kamerun National Congress (KNC) won the elections to be conducted following the collapse of the Macpherson Constitution, the question of the Southern Cameroons legislature would be a foregone conclusion [Ngoh, 1990: 88-90; Chem, 1976:60].

The 1953 elections was centered on the issue of whether the Southern Cameroons should, or should not, remain part of the Eastern Region. In the end, the elections were won decisively by the KNC of Dr. Endeley by 12 out of the 13 contested seats. The remaining seat was won by the Kamerun People Party (KPP), which favoured a continued stay in Eastern Nigeria.

1953 proved to be a turning point in the history of Southern Cameroons in particular and Nigeria in general. For the first time the British recognized explicitly a separate identity for Southern Cameroons albeit on a condition. The condition was fulfilled. There was no turning back. More would have to be gained not lost.

The Lagos conference of January - February, 1954, consequently granted the Southern Cameroons quasi-federal status within the federation of Nigeria. In a policy statement at the conference, the Secretary of State for Colonies revealed that: 'Dr. Endeley told me that the Southern Cameroons did not wish to leave the federation.... Southern Cameroons would cease to be part of the Eastern Region, but would remain part of the federation of Nigeria and quasi Federal Territory' [Mbile N.N., 200:8082]. It had a legislature and an executive of its own. Thereafter Nigeria had four regions by every practical definition. The first session of the Southern Cameroons house of Assembly met on October 26, 1954. 
Following the decisions of the London Constitutional Conference of 1957, it was agreed that the term quasi federal territory would be abolished and the territory became known as Southern Cameroons with a full self-governing region within Nigeria by 1958. It had an executive council, a reserved legislature, a judiciary and a public service of its own. To confirm its full regional status, it was reserved 12 seats out of the 320 seats in the Nigerian federal Senate in Lagos [Ngoh V.C. 1990:108-112].

But in 1959 the KNDP of J.N. Foncha, which wanted Cameroons to leave Nigeria completely, won the elections and became the ruling party in Southern Cameroons. In 1961, the party succeeded in convincing the Cameroonians to vote to secede from Nigeria and unify with the Republic of Cameroon. By such attainment, the Southern Cameroons reunified with the Republic of Cameroon on October $1^{\text {st }}$, 1961, to form the Federal Republic of Cameroon. Nigeria once more returned to a federation of three regions until 1963 when the Mid -West region was created.

\section{Conclusion}

This article elucidates the consequences of the thorny relations that existed between Southern Cameroons and Nigerian federal governance from 1916 when Britain administered her as an appendage of Nigeria. Such relations which were asymmetric placed Southern Cameroons in disadvantageous position and created an atmosphere of distrust which provoked the demands for a separate region within Nigeria as a rescue from Nigerian haughty. In their feud for regional autonomy Southern Cameroons became a catalyst in the evolution of Nigerian federation and took Nigeria from three to four regions when she was granted a quasi-regional and full regional status in 1954 and 1959 respectively. That became a turning point in the history of Nigeria as at independence Nigeria once more returned to a three state federation. On this count, the British Southern Cameroons factor becomes inescapable in any discussion on the history of the evolution of Nigerian federation.

\section{References}

1. Aka, A. E. (2002). The British Cameroons 1922-1961: A study in colonialism and under development, Platteville-Madison, Nkemnji Global Tech.

2. Amaazee, V.B. (2000). The Eastern Nigerian Regional Crisis and the destiny of British Southern Cameroons, 1953-1954, Yaoundé, Presses Universitaire de Yaoundé.

3. Chem-Langhëë, B. (1976). Kamerun plebiscites 1959-1961: Perceptions and strategies, Ph.D Theses, University of British Columbia.

4. DeLancey, M.D., Mbuh, R.N., DeLancey, M.W. (2010). Historical dictionary of the Republic of Cameroon, Fourth Edition, the Scarecrow Press, Inc. Lanham, Maryland *Toronto* Plymouth. U.K.

5. Ebune, B. J. (1992). The growth of political parties in Southern Cameroons, 1916-1960, Yaoundé, CEPER.

6. Elango, Z. L. (1987). The Anglo-French Condominium in Cameroon, 1914-1916: History of misunderstanding, Limbe,, Navi Group Limbe.

7. Eyongetah, T. and Brain, R. (1974). A history of the Cameroon, Essex, London.

8. Kale, P.M. (1967). Political evolution in the Cameroons, Buea, Government Printer.

9. Le Vine, V. (1961). Reluctant bride? The other Cameroon, African Report.

10. Mbile, N.N. (2000). Cameroon political story: Memories of an authentic eye witness, Limbe, Presbyterian Printing Press, Limbe. 
11. Ngoh, V.J. (1987).Cameroon 1884-1985: A hundred years of history, Yaounde, Navi Group Publication.

12. (1990). Southern Cameroons, 1922 - 1961: A constitutional history, Ashgate, Aldershot, Sydney.

13. O'Connell, J. (1967). Political integration: The Nigeria case, in (ed.), Arthur Haxlewood, African integration and disintegration, London, Oxford University Press.

14. Willard, R. J. (1970). The Cameroon federation: Political integration in a fragmented society, Princeton University Press, Princeton, New Jersey

\section{Reports and Archival Material}

1. U.N. Trusteeship council, petition from the Cameroon National Federation concerning the Cameroons under British and French administrations, See NAB, T/ 114, annex.II, 1949, p.54

2. Federation report of the commission on allocation of revenue, Lagos Government print, 1951.

3. NAB, File No.Pc/h (1946)1, Conditions of settlement from the Senior District Officer for Victoria Division to the Resident, Cameroon Province, Buea, 1948, to the Secretary, Eastern Province, Enugu, June 29, 1948

4. NAB, Pc(1948)1, conditions of settlement. District Officer, Victoria to the Resident, Cameroons Province, March, 1948

5. United Nations visiting mission to trust territories in West Africa in 1949, New York, 1951.

6. Proceedings of the general conference on constitutional reforms, 1950, Lagos, Government Printers, 1950. 